\title{
PENGARUH CURRENT RATIO DAN DEBT TO EQUITY RATIO TERHADAP EARNING AFTER TAX PADA PT. INDOFOOD SUKSES MAKMUR, TbK PERIODE 2009-2016
}

\author{
Pranoto $^{1)} \&$ Medawati $^{2)}$ \\ 1) 2) dosen Universitas Pamulang, email : : pranoto140688@unpam.ac.id
}

\section{ARTICLES}

INFORMATION

\section{ABSTRACT}

\section{JURNAL SEKURITAS \\ (Saham, Ekonomi, Keuangan dan Investasi ) \\ Vol.1, No.3, Maret 2018 \\ Halaman : $182-194$ \\ (c) LPPM \& Prodi Manajemen \\ UNVERSITAS PAMULANG \\ ISSN (online) : 2581-2777 \\ ISSN (print) : :2581-2696}

Keyword :

Current Ratio (CR), Debt to

Equity Ratio (DER)) dan

Earning After Tax (EAT)

JEL. classification :

C31, E50

\section{Contact Author :}

PRODI MANAJEMEN UNPAM

JL.Surya Kencana No.1 Pamulang

Tangerang Selatan - Banten

Telp. (021) 7412566, Fax (021) 7412491

Email :

jurnalfinance.unpam@gmail.com
Tujuan penelitian ini adalah untuk mengetahui Pengaruh Current Ratio (CR) Terhadap Earning After Tax (EAT) ,untuk mengetahui Pengaruh Debt to EquityRatio (DER) dan untuk mengetahui Pengaruh Current Ratio (CR) dan Debt to EquityRatio (DER) Terhadap Earning After Tax (EAT) Perusahaan Pada PT. Indofood Sukses Makmur (2009 - 2016).

Metode penelitianyang dilakukan penulis dalam menyusun skripsi ini deskriptif kuantitatif yaitu melakukan pembahasan atas permasalahan yang dihadapi perusahaan terhadap kinerja perusahaan dari segi kuangan. Data analisis yang digunakan adalah data sekunder yang didapat dari anual report laporan keuangan.Sampel yang digunakan ini berupa laporan keuangan neraca dan laba rugi pada PT. Indofood Sukses Makmur,tahun 2009 sampai dengan tahun 2016. Untuk mengetahui ada tidaknya pengaruhPengaruh Current Ratio (CR) dan Debt to Equity Ratio (DER) Terhadap Earning After Tax (EAT). Pengujian yang digunakan pada penelitian ini adalah analisa deskipsi statistik ,analisa korelasi ,koefesien determinasi ,uji regresi linier berganda uji (t)dan uji ( $f$ )

Variabel Current Ratio (CR) thitung sebesar (-0.558) dengan signifikasi 0.601 , dan Ttabel 2,57058 .Karena Thitung $0558<$ Ttabel 2,57058, dan signifikasi 0,601>0,05 Jadi dapat disimpulkan bahwa Current Ratio secara parsial berpengaruh negatif dan tidak signifikan terhadap Earning After Tax Pada PT. Indofood Sukses Makmur, Tbk Tahun 2009-2016. Berdasarkan tabel diatas menunjukan nilai Thitung sebesar (-1.822) dengan signifikasi 0.128 , dan Ttabel 2,57058 .Karena Thitung (- 1.822 ) $<$ Ttabel 2,57058, dan signifikasi 0,128 > 0,05 . Jadi dapat disimpulkan bahwa Debt to Equity Ratio secara parsial berpengaruh negatif dan tidak signifikan terhadap Earning After Tax.3.Fhitung $=2,898$, signifikasi sebesar 0,146 . Nilai Fhitung $2,898<$ Ftabel 5,79, nilai signifikasi $0,146>0,05$. Maka dapat disimpulkan bahwa variable independen (Current Ratio dan Debt to Equity Ratio) berpengaruh positif dan tidak signifikan terhadap nilai variabel dependen (Earning After Tax) 


\section{A. Pendahuluan}

Pada saat sekarang ini perkembangan ekonomi banyak memberikan perubahan dalam perekonomian nasional terutama semakin ketatnya dunia persaingan bisnis. Perkembangan dunia usaha yang semakin ketat saat ini telah menciptakan suatu persaingan antar perusahaan.

Persaingan mendorong setiap perusahaan yang berkompetisi harus dapat menentukan strategi yang tepat dalam mengambil tindakan dan kebijakan dalam menjalankan kegiatan operasional usahanya sehingga dapat menciptakan keunggulan bersaing yang akan menentukan posisinya untuk menjaga kelangsungan perusahaan dengan baik agar perusahaan dapat berkembang sesuai dengan kegiatan yang dijalankan pada masa yang akan datang.

Dalam mencapai keunggulan dan mempertahankan perusahaan, perusahaan diharapkan memiliki kemampuan yang kuat diberbagai bidang seperti bidang keuangan, pemasaran, dan bidang sumber daya manusia serta teknologinya itu sendiri.

Tersingkirnya suatu perusahaan dari perekonomian disebabkan olehketidakmampuan perusahaan dalam memperoleh laba.Untuk memperoleh laba perusahaan harus melakukan kegiatan operasional yang didukung adanya sumber daya. Dalam penelitian ini laba yang digunakan dalam mengukur kinerja perusahaan adalah laba bersih setelah pajak.

Ada beberapa teknik analisis yang dapat digunakan untuk menganalisis dan menilai kondisi keuangan perusahaan serta prospek perubahan labanya. Salah satu alternatif untuk mengetahui apakah informasi keuangan yang dihasilkan dapat bermanfaat untuk memprediksi perubahan laba, termasuk kondisi keuangan di masa depan adalah dengan melakukan analisis rasio keuangan. Dalam penelitian ini terdapat 2 (dua) kategori rasio keuangan yang digunakan yaitu (1) Current Ratio dan (2) Debt to Equity Ratio.

Pengukuran current ratio (CR) didasarkan pada perbandingan aktiva lancar dengan hutang jangka pendek yang harus dibayarkan oleh perusahaan. Tingginya hasil current ratio (CR) yang didapat akan semakin baik bagi kreditur karena perusahaan dianggap mampu untuk dapat melunasi segala kewajibannya, namuncurrentratio(CR) yang tinggi bagi pemegang saham akan kurang menguntungkan (Djarwanto, 2010:150). Current ratio(CR) yang rendah juga relatif lebih riskan, namun menunjukkan bahwa manajemen menggunakan aktiva lancarnya dengan efektif untukmeningkatkan keuntungan (Djarwanto, 2010:150). Hal ini menunjukkan bahwa tinggi rendahnya CR akan mempengaruhi keuntungan yang akan diperoleh.

Besarnya perbandingan antara total hutang dengan modal yang dimiliki perusahaan dapat dihitung dengan menggunakan Debt to equity ratio (DER). Hasil debt to equity ratio (DER) yang rendah akan dapat menunjukkan tingginya tingkat pendanaan yang mampu diberikan pemegang saham bagi perusahaan. Rendahnya hasil debt to equity ratio (DER) juga akan perlindungan yang semakin besar bagi kreditur apabila perusahaan mengalami kerugian besar maupun penurunan nilai aset, sehingga debt to equity ratio (DER) yang rendah secara umum lebih disukai dan dianggap baik oleh kreditur (Horne dan Wachowicz, 2012:169).

Dari uraian diatas dapat dilihat dan disimpulkan dari keseluruhan rasio Current Ratio dan Debt to Equity Ratio yang kecenderungan mengalami penurunan secara bersamaaan setiap tahunnya akan mempengaruhi peningkatan pada Earning After Tax pada PT Indofood Sukses Makmur Tbk setiap tahunnya dan sebaliknya setiap rasio Current Ratio dan Debt to Equity Ratio yang kecenderungan mengalami peningkatan secara PT . Indofood Sukses Makmur Tbk.

Berdasarkan uraian di atas,penulis tertarik untuk melakukan penelitian yang berjudul: "Pengaruh Current Ratio dan Debt to Equity Ratio Terhadap Earning After Tax Perusahaan PT . Indofood Sukses Makmur Tbk Periode 2009 - 2016. 


\section{B. Tujuan dan Manfaat Penelitian}

Tujuan dan manfaat penelitian dilakukan adalah untuk memperoleh data dan informasi yang diperlukan, kemudian diolah sebagai bahan perbandingan dengan teori dari studi keperpustakaan guna memenuhi persyaratan untuk penelitian.

\section{Tujuan Penelitian}

Adapun tujuan dari penelitian ini adalah :

a. Untuk mengetahui pengaruh Current Ratio terhadap Earning After Tax pada perusahaan PT. Indofood Sukses Makmur Tbk (2009-2016).

b. Untuk mengetahui pengaruh Debt to Equity Ratio terhadap Earning After Tax pada perusahaan PT. Indofood Sukses Makmur Tbk (2009 - 2016).

c. Untuk Mengetahui pengaruh Current Ratio dan Debt to Equity Ratio, secara simultan terhadap Earning After Tax pada Perusahaan PT. Indofood Sukses Makmur Tbk (2009-2016)

\section{Manfaat Penelitian}

a. Manfaat Praktis Bagi Perusahaan,

Hasil penelitian ini diharapkan menjadi masukan dan pertimbangan dalam mengevaluasi prosedur dan kebijakan yang berkaitan dengan Current Ratio, Debt to Equity Ratio terhadap Earning After Tax.

b. Manfaat Teoritis

1) Bagi Penulis

Dalam penelitian ini peneliti dapat menambah wawasan dan gan dengan pengaruh rasio - rasio keuangan terhadap laba setelah pajak.

2) Bagi Universitas

Hasil penelitian ini diharapkan berguna sebagai bahan referensi baik dari segi perspektif internal maupun eksternal juga berguna sebagai bahan referensi

\section{Landasan Teori}

\section{a. Manajemen Keuangan}

\section{Pengertian manajemen secara umum}

Pengertian Manajemen adalah suatu seni dalam ilmu dan proses pengorganisasian seperti perencanaan, pengorganisasian, pergerakan, dan pengendalian atau pengawasan. Dalam pengertian manajemen sebagai seni karna seni berfungsi dalam mewujudkan tujuan yang nyata dengan hasil atau manfaat sedangkan manajemen sebagai ilmu yang berfungsi menerangkan fenomena-fenomena, kejadian sehingga memberikan penjelasan yang sebenarnya.

Manajemen berasal dari bahasa inggris yaitu "Manage" yang berarti, mengurus, mengelola, mengendalikan, mengusahakan, memimpin.Sedangkan Pengertian Manajemen secara etimologis adalah seni melaksanakan dan mengatur. Pengertian manajemen juga dipandang sebagai disiplin ilmu yang mengajarkan proses mendapatkan tujuan organisasi dalam upaya bersama dengan sejumlah orang atau sumber milik organisasi. Orang yang melakukan manajemen disebut dengan manajer.

Pengertian manajemen atau definisinya secara umum memang memiliki banyak sudut pandang dan persepsi. Namun dalam hal visi dan tujuannya, kesemua pengertian tersebut akan mengerucut kepada satu hal,yaitu pengambilan keputusan.

Manajemen adalah ilmu yang sangat luas, bahkan belum jelas asal-usul ilmu ini mulai ada.Karena ilmu manajemen adalah ilmu yang sangat berguna bukan hanya dalam ilmu bisnis tetapi juga dalam kehidupan sehari-hari.

\section{Pengertian manajemen menurut para ahli}

Menurut Ismail Solihin (2009:4) manajemen dapat didefiniskan sebagai "proses perencanaan, pengorganisasian, kepemimpinan dan pengendalian 
dari berbagai sumber daya organisasi untuk mencapai tujuan secara efektif dan efisien.

Manajemen menurut Malayu S.P. Hasibuan (2010:1) adalah ilmu dan seni mengatur proses pemanfaatan sumber daya manusia dan sumber - sumber lainnya secara efektif dan efisien untuk mencapai tujuan tertentu.

Sementara itu Menurut Kosasih dan Soewedo (2010:1) Manajemen yaitu pengarahan mengerakkan sekelompok orang dan fasilitas dalam usaha untuk mencapai tujuan tertentu. Sedangkan menurut T. Hani Handoko (2011:8) menjelaskan bahwa manajemen adalah proses perencanaan, pengorganisasian, pengarahan, dan pengawasan usaha-usaha para anggota organisasi dan kegunaan sumber daya - sumber daya organisasi lainnya agar mencapai tujuan organisasi yang telah ditetapkan.

Manajemen adalah proses kegiatan menggerakkan sekelompok orang dan menggerakan fasilitas yang tersedia untuk mencapai tujuan tertentu Abdulrahmat Fatoni (2011:3).

Berdasarkan pengertian Manajemen diatas dapat ditarik kesimpulan bahwa Manajemen adalah proses perencanaan, pengorganisasian, penggerakkan dan pengendalian untuk mencapai tujuan tertentu melalui sumber daya manusia secara efektif dan efisien.

1. Pengertian Manajemen Keuangan

Menurut Kasmir (2010:5) dalam pengantar manajemen keuangan yang dikutip dari James C. Van Home, manajemen keuangan adalah segala aktivitas yang berhubungan dengan pengelolaan, pendanaan dan pengelolaan aktiva dengan beberapa tujuan menyeluruh.

Manajemen keuangan menurut Martono dan Agus Harjito (2011:4) Manajemen Keuangan adalah segala aktivitas perusahaan yang berhubungan dengan bagaimana memperoleh dana, menggunakan dana dan mengelola asset sesuai tujuan perusahaan secara menyeluruh.

Menurut J Fred Weston dan Thomas E.Copeland (2009:3) dalam bukunya manajemen keuangan mengemukakan tentang manajemen keuangan dari segi yang lain, pengertian manajemen keuangan dapat dirumuskan dari tugas dan tanggung jawab para manajer keuangan. Meskipun tugas dan tanggung jawab berbeda-beda pada setiap perusahaan, namun tugas pokok manajemen keuangan antara lain menyangkut keputusan tentang penanaman modal, pembagian kegiatan usaha, dan pembagian deviden pada berbagai perusahaan.

Menurut Bambang Riyanto (2010:11) Manajemen keuangan dimaksudkan sebagai manajer perusahaan yang bertanggung jawab atas pengambilan keputusan penting mengenai investasi dan pendanaan.

Sementara itu menurut Nandi Juhandi (2010:2) Manajemen Keuangan (financial management) merupakan semua aktivitas perusahaan yang berhubungan dengan usaha untuk memperoleh dana dari alternatif biaya yang paling murah serta penggunaan dari pengalokasian dana untuk operasi maupun ekspansi perusahaan secara efisien.

Dari beberapa uraian diatas dapat ditarik kesimpulan bahwa pengertian manajemen keuangan adalah aktivitas memperoleh dana, menggunakan dana, dan mengelola asset sesuai dengan tujuan perusahaan secara efisien.

2. Fungsi Manajemen Keuangan

Manajemen keuangan merupakan manajemen (pengelolaan) mengenai bagaimana memperoleh aset, mendanai aset dan mengelola aset untuk mencapai tujuan perusahaan. Dari definisi tersebut menurut Martono 
dan Agus(2010:4 ) ada 3 (tiga) fungsi utama dalam manajemen keuangan, yaitu:

a. Keputusan Investasi (Investment Decision)

Keputusan investasi merupakan keputusan terhadap aktiva apa yang akan dikelola oleh perusahaan. Keputusan investasi adalah yang paling penting diantara ketiga keputusan lainnya. Hal ini dikarenakan keputusan investasi berpengaruh secara langsung terhadap besarnya rentabilitas investasi dan aliran kas perusahaan untuk waktu yang akan datang.

b. Keputusan Pendanaan (Financing Decision)

Keputusan pendanaan ini menyangkut beberapa hal. Pertama, keputusan mengenai penetapan sumber dana yang diperlukan untuk membiayai investasi. Sumber dana yang akan digunakan untuk membiayai investasi tersebut dapat berupa hutang jangka pendek, hutang jangka panjang, dan modal sendiri. Kedua, penetapan perimbangan pembelanjaan yang terbaik atau sering disebut struktur modal yang optimum. Struktur modal optimum merupakan perimbangan hutang jangka panjang dan modal sendiri dengan biaya modal rata - rata minimal.

c. Keputusan Pengelolaan Aset (Assets Management Decision)

Apabila aset telah diperoleh dengan pendanaan yang tepat, maka asset - aset tersebut memerlukan pengelolaan secara efisien. Pengalokasian dana yang digunakan untuk pengadaan dan pemanfaatan aset menjadi tanggung jawab manajer keuangan. Tanggung jawab tersebut menuntut manajer keuangan untuk lebih memperhatikan pengelolaan aktiva lancar dari pada aktiva tetap.

3. Tujuan Manajemen Keuangan

Menurut Darsono (2009:4) ada beberapa tujuan manajemen keuangan, antara lain:

a. Memaksimalkan kekayaan pemegang saham.

b. Menjaga kekayaan pihak-pihak yang berkepentingan.

c. Memaksimalkan laba.

Selanjutnya menurut Suad Husnan (2010:6) tujuan manajemen keuangan adalah "Untuk mengambil keputusan-keputusan keuangan yang benar, keputusan keuangan adalah untuk memaksimumkan nilai perusahaan".

Sedangkan menurut Irham Fahmi (2012:4) tujuan manajemen keuangan yaitu:

a. Memaksimumkan nilai perusahaan.

b. Menjaga stabilitas finansial dalam keadaan yang selalu terkendali.

c. Memperkecil risiko perusahaan dimasa sekarang dan yang akan datang.

\section{b. Laporan Keuangan}

1. Pengertian Keuangan

Keuangan menurut Darsono (2012:2) adalah ilmu dan seni dalam mengelola uang. Yang dimaksud mengelola uang ialah aktivitas untuk memperoleh sumber capital (modal) dengan biaya yang semurah murahnya dan menggunakannya seefektif dan seefisien mungkin.

Menurut Bambang Riyanto (2011:12) Keuangan disebut juga dengan pembelanjaan yaitu keseluruhan usaha untuk mempersiapkan dan mengatur penggunaan dana dimana disini juga termasuk perencanaan beserta pelaksanaannya.

Sementara itu Lawrence J. Gitman (2013:4) mengatakan Keuangan dapat didefiniskan sebagai suatu seni dan ilmu pengetahuan dari pengelolaan 
uang.Sesungguhnya setiap individu dan organisasi menghasilkan uang dan membelanjakan atau menginvestasikan uang. Keuangan berhubungan dengan proses, institusi, pasar dan instrumen yang terlibat dalam perpindahan atau transfer uang antara individu, bisnis dan pemerintah.

Dari beberapa uraian di atas dapat ditarik kesimpulan bahwa pengertian keuangan adalah melakukan pengelolaan uang dalam organisasi maupun individu untuk memperoleh sumber dana dan menggunakan dana secara efektif dan efisien.

2. Pengertian Laporan Keuangan

Menurut Sofyan Syafri Harahap (2009:105), laporan keuangan menggambarkan kondisi keuangan dan hasil usaha suatu perusahaan pada saat tertentu atau jangka waktu tertentu. Adapun jenis laporan keuangan yang lazim dikenal adalah neraca, laporan laba-rugi atau hasil usaha, laporan peruabahan ekuitas, laporan arus kas, laporan posisi keuangan..

Menurut Munawir (2010: 5), pada umumnya laporan keuangan itu terdiri dari neraca dan perhitungan laba-rugi serta laporan perubahan ekuitas. Neraca menunjukkan/menggambarkan jumlah aset, kewajiban dan ekuitas dari suatu perusahaan pada tanggal tertentu.

Sedangkan perhitungan (laporan) laba-rugi memperlihatkan hasil-hasil yang telah dicapai oleh perusahaan serta beban yang terjadi selama periode tertentu dan perubahan ekuitas menunjukkan sumber dan penggunaan atau faktor-faktor yang menyebabkan perubahan ekuitas perusahaan.

Menurut Ikatan Akuntan Indonesia (2012:5) laporan keuangan yaitu struktur yang menyajikan posisi keuangan dan kinerja keuangan dalam sebuah entitas.Tujuan umum dari laporan keuangan ini untuk kepentingan umum adalah penyajian informasi mengenai posisi keuangan (financial position), kinerja keuangan (financial performance), dan arus kas (cash flow) dari entitas yang sangat berguna untuk membuat keputusan ekonomis bagi para penggunannya.

Untuk dapat mencapai tujuan ini, laporan keuangan harus menyediakan informasi mengenai elemen dari entitas yang terdiri dari aset, kewajiban, modal sendiri, beban, dan perubahan ekuitas dan arus kas. Informasi tersebut diikuti dengan catatan, akan membantu pengguna memprediksi arus kas masa depan.

Berdasarkan beberapa pengertian di atas dapat disimpulkan bahwa laporan keuangan untuk perusahan terdiri dari laporan-laporan yang melaporkan posisi keuangan perusahaan pada suatu waktu tertentu, yang dilaporkan arus kas, dimana neraca menunjukkan jumlah aset, kewajiban dan ekuitas perusahaan.

Laporan laba-rugi menunjukkan hasil operasi perusahaan salaam periode tertentu.Sedangkan laporan perubahan ekuitas menunjukkan sumber dan penggunaan atau faktor-faktor yang menyebabkan perubahan ekuitas perusahaan.

3. Tujuan Laporan Keuangan

Menurut Irham Fahmi (2011:28) tujuan utama dari laporan keuangan adalah untuk memberikan informasi keuangan yang mencangkup peruabahan dari unsur-unsur laporan keuangan yang ditujukan kepada pihak-pihak lain yang berkepentingan dalam menilai kinerja keuangan terhadap perusahaan di samping pihak manajemen perusahaan.

Para pengguna laporan akan menggunakannya untuk meramalkan, membandingkan, dan menilai dampak keuangan yang timbul dari keputusan ekonomis yang diambilnya. 
Informasi mengenai dampak keuangan yang timbul sangatlah berguna bagi pengguna untuk meramalkan, membandingkan dan menilai keuangan yang mana jika nilai uang tidak stabil, maka dapat dijelaskan dalam laporan keuangan. Laporan keuangan akan lebih bermanfaat jika yang dilaporkan tidak saja aspek-aspek kuantitatif, tetapi mencakup penjelasan-penjelasan lainnya yang dirasakan perlu. Dan informasi ini harus faktual dan dapat diukur secara objektif.

Laporan keuangan dapat jelas memperlihatkan gambaran kondisi keuangan dari perusahaan. Laporan keuangan yang merupakan hasil dari kegiatan operasi normal perusahaan akan memberikan informasi keuangan yang berguna bagi entitas-entitas di dalam perusahaan itu sendiri maupun entitas-entitas lain diluar perusahaan.

Dari beberapa tujuan laporan keuangan diatas, maka dapat disumpulkan :

a. Informasi posisi laporan keuangan yang dihasilkan dari kinerja dan aset perusahaan sangat dibutuhkan oleh para pengguna laporan keuangan, sebagai bahan evaluasi dan perbandingan untuk melihat dampak keuangan yang timbul dari keputusan ekonomis yang diambilnya.

b. Informasi keuangan perusahaan diperlukan juga untuk menilai dan meramalkan apakah perusahaan di masa sekarang dan di masa yang akan datang sehingga akan menghasilkan keuntungan yang sama atau lebih menguntungkan.

c. Informasi perubahan posisi keuangan perusahaan bermanfaat untuk menilai aktivitas investasi, pendanaan dan operasi perusahaan selama periode tertentu. Selain untuk menilai kemampuan perusahaan, laporan keuangan juga bertujuan sebagai bahan pertimbangan dalam pengambilan keputusan investasi.

d. Memberikan informasi keuangan yang dapat dipercaya dan bermanfaat bagi investor dan kreditor untuk dasar pengambilan kepututsan investasi dan pemberian kredit.

4. Karakteristik Laporan Keuangan

Menurut Ikatan Akuntan Indonesia (2011:5-5-8), laporan keuangan yang berguna bagi pengguna informasi bahwa harus terdapat empat karakteristik kualitatif pokok yaitu dapat dipahami, relevan, keandalan, dan dapat diperbandingkan.

a. Dapat Dipahami

Kualitas penting informasi yang ditampung dalam laporan keuangan adalah kemudahannya untuk segera dapat dipahami oleh para pemakai. Dalam hal ini, pemakai diasumsikan memiliki pengetahuan yang memadai tentang aktifitas ekonomi dan bisnis, akuntansi serta kemauan untuk mempelajari informasi dengan ketentuan yang wajar.

Namun demikian, informasi kompleks yang seharusnya dimasukan dalam laporan keuangan tidak dapat dikeluarkanhanya atas dasar pertimbangan bahwa informasi tersebut terlalu untuk dapat dipahami oleh pemakai tertentu.

b. Relevan

Agar bermanfaat, informasi harus relevan untuk memenuhi kebutuhan pemakai dalam proses pengambilan keputusan. Informasi memiliki kualitas relevan apabila informasi tersebut dapat mempengaruhi keputusan ekonomi pemakai dengan membantu mereka mengevaluasi peristiwa masa lalu, masa kini, atau masa depan, atau mengoreksi hasil evaluasi mereka dimasa lalu.

c. Keandalan 
Agar bermanfaat, informasi juga harus andal. Informasi memiliki kualitas andal jika bebas dari pengertian menyesatkan, kesalahan material, dan dapat diandalkan pemakainya sebagai penyajian yang tulus atau jujur dari yang seharusnya disajikan, atau yang secara wajar diharapkan dapat disajikan. Selain itu informasi harus diarahkan pada kebutuhan pemakai, dan tidak bergantung pada kebutuhan atau keinginan pihak tertentu.

Dalam hal menghadapi ketidakpastian peristiwa dan keadaan tertentu, maka ketidakpastian tersebut diakui dengan mengungkapkan hakikat dan tingkatnya dengan menggunakan pertimbangan sehat. Agar dapat diandalkan, informasi yang disajikan dalam laporan keuangan harus lengkap dalam batasan materialistis dan biaya (kelengkapan). Kesenjangan untuk tidak mengungkapkan dapat mengakibatkan informasi menjadi tidak benar dan menyesatkan.

d. Dapat Dibandingkan

Pemakai laporan keuangan harus dapat memperbandingkan laporan keuangan perusahaan antar periode untuk mengidentifikasi kecenderungan posisi keuangan. Pemakai juga harus dapat memperbandingkan laporan keuangan antar perusahaan untuk mengevaluasi posisi keuangan, serta perusahaan posisi keuangan secara relatif.Oleh karena itu, pengukuran dan penyajian dampak keuangan dari transaksi dan peristiwa lain yang serupa harus dilakukan secara konsisten untuk perusahaan tersebut, antara periode yang sama, dan untuk perusahaan yang berbeda.

5. Jenis - Jenis Laporan Keuangan

Laporan keuangan menggambarkan dampak keuangan dari transaksi dan peristiwa lain yang diklasifikasikan dalam beberapa kelmpok ekonomi yang merupakan unsur-unsur laporan keuangan. Macam-macam komponen laporan keuangan tersebut adalah :

a. Laporan Neraca

Menurut Brealey, Myers, dan Marcus (2012:56) perusahaan perlu mendapatkan kas untuk memperoleh banyak aset yang digunakan dalam bisnis mereka. Dalam proses mendapatkan kas tersebut, mereka juga menanggung kewajiban pada pihak-pihak yang memberikan dana.

Neraca memberikan potret aset (aktiva) dan kewajiban perusahaan aset terdiri dari aset yang bisa dengan cepat dicairkan menjadi kas dan aset tetap seperti pabrik dan mesin.Kewajiban meliputi kewajiban lancar yang wajib dilunasi dalam jangka waktu satu tahun dan hutang jangka panjang.Selisih antara aset dan kewajiban menampilkan jumlah ekuitas pemegang saham.

b. Laporan Laba-Rugi

Menurut Brealey, Myers, dan Marcus (2012:61) laporan laba rugi memperlihatkan seberapa menguntungkankah perusahaan selama tahun bersangkutan. Laporan laba-rugi adalah laporan keuangan yang memperlihatkan pendapatan, beban, dan laba bersih perusahaan selama periode tertentu.

c. Laporan Arus Kas

Sangat penting untuk mengetahui perputaran arus dana yang berada di perusahaan, kemana dana atau kas pergi dan dari mana kas masuk. Hal ini supaya perusahaan dapat mengontrol dana atau kas perusahaan yang dimiliki selama ini. Laporan arus kas atau Cash Flow berfungsi untuk memberikan informasi mengenai arus kas masuk dan kas keluar.Laporan mengenai arus kas masukdilihat dari beberapa sumber, 
yaitu hasil dari kegiatan operasional dan kas yang diperoleh dari pendanaan atau pinjaman.

Sedangkan arus kas keluar dapat dilihat dari berapa banyak beban biaya yang dikeluarkan perusahaan, baik untuk kegiatan operasional atau investasi pada bisnis lain.

d. Laporan Sumber dan Penggunaan Dana

Padalaporan ini dimuat sumber dan pengeluaran perusahaan selama satu periode.Dana bisa diartikan kas dan bisa juga diartikan sebagai modal kerja.

\section{Hasil Penelitian dan Pembahasan}

\section{Analisis Data}

\section{a. Current Ratio}

Current Ratio, merupakan rasio untuk mengukur kemampuan perusahaan membayar kewajiban jangka pendek atau utang yang segera jatuh tempo pada saat ditagih secara keseluruhan. Dengan kata lain, seberapa banyak aktiva lancar yang tersedia untuk menutupi kewajiban jangka pendek yang segera jatuh tempo. Current Ratio dapat pula dikatakan sebagai bentuk untuk mengukur tingkat keamanan (margin of safety) suatu perusahaan.

$$
\text { CurrentRatio }=\stackrel{\text { Aktiva Lancar }}{\text { Hutang Lancar }}_{\mathrm{x}} 100 \%
$$

Berdasarkan tabel 4.1, diketahui bahwa perkembangan current ratio (CR) PT. Indofood Sukses Makmur,Tbk dapat dianalisis perkembangan dari tahun 2009-2016 mengalami ketidakstabilan. Pada tahun 2010 CR mengalami peningkatan sebesar $87,3 \%$ menjadi $203,6 \%$, tahun 2011 CR mengalami

penurunan sebesar $12,7 \%$ menjadi $190,9 \%$, pada tahun 2012 CR mengalami peningkatan sebesar $13,9 \%$ menjadi 204,8\%, pada tahun 2013 CR mengalami penurunan sebesar $38,1 \%$ menjadi $166,7 \%$, pada tahun $2014 \mathrm{CR}$ mengalami peningkatan sebesar 14 , \% menjadi 180,7\%, pada tahun $2015 \mathrm{CR}$ mengalami penurunan sebesar $10,2 \%$ menjadi $170,5 \%$ dan tahun $2016 \mathrm{CR}$ mengalami penurunan kembali sebesar $19,7 \%$ menjadi $150.8 \%$..

Dari hasil penelitian ini diketahui naik turunnya CR dipengaruhi oleh kemampuan perusahaan dalam membayar hutang jangka pendeknya.

b. Debt to Equity Ratio

Merupakan rasio yang digunakan untuk menilai hutang dengan ekuitas. Untuk mencari rasio ini dengan cara membandingkan antara seluruh utang, termasuk utang lancar dengan seluruh ekuitas. Rasio ini berguna untuk mengetahui jumlah dana yangdisediakan peminjam (kreditor) dengan pemilik perusahaan. Dengan kata lain rasio ini untuk mengetahui setiap rupiah modal sendiri yang dijadikan untuk jaminan utang. Adapun rumus yang digunakan untuk menghitung rasio ini yaitu:

Debt to Equity Ratio $=\frac{\text { Total Hutang }}{\text { Total Ekuitas }} \times 100 \%$

Dapat dilihat pada tabel 4.2debt to equity ratio (DER) mengalami penurunan dan peningkatan. Penurunan rasio ini dapat disebabkan karena adanya 
hutang perusahaan yang sudah lunas, sehingga jumlah hutang berkurang dari tahun sebelumnya. Sedangkan meningkatnya rasio ini dapat disebabkan karena total hutang yang meningkat, total hutang yang meningkat dapat disebabkan karena perusahaan memperoleh penambahan dana dari pihak kreditor.

c. Earning After Tax

Dalam penelitian ini adalah jumlah dari pendapatan operasional dan non operasional yang dikurangi dengan pajak penghasilan, dengan tolak ukur yang digunakan dalam penelitian adalah

$$
\begin{aligned}
& \text { Earning After Tax = Laba Operasional - } \\
& \text { Pajak Penghasilan }
\end{aligned}
$$

\section{Tabel 4.3}

Perkembangan Earning After Tax (EAT) PT. Indofood Sukses Makmur,Tbk Pada Tahun 2009 -2016

\begin{tabular}{|c|c|c|c|c|}
\hline Tahun & $\begin{array}{c}\text { (Rugi)/Laba } \\
\text { Operasional dan } \\
\text { Non Operasional }\end{array}$ & $\begin{array}{c}\text { (Beban)/ } \\
\text { Manfaat } \\
\text { Pajak } \\
\text { Penghasilan }\end{array}$ & $\begin{array}{c}\text { (Loss) / } \\
\text { Earning } \\
\text { After } \\
\text { Tax (Rp) }\end{array}$ & $\begin{array}{c}\Delta \text { Kenaikan / } \\
\text { Penurunan } \\
\text { (Rp) }\end{array}$ \\
\hline 2009 & $4,063,813$ & $1,207,032$ & $2,856,781$ & - \\
\hline 2010 & $5,432,375$ & $1,497,567$ & $3,934,808$ & $1,078,027$ \\
\hline 2011 & $6,352,389$ & $1,460,716$ & $4,891,673$ & $9,568,65$ \\
\hline 2012 & $6,309,756$ & $1,530,310$ & $4,779,446$ & $(112,227)$ \\
\hline 2013 & $4,668,707$ & $1,250,072$ & $3,416,635$ & $(1,362,811)$ \\
\hline 2014 & $7,085,428$ & $1,855,939$ & $5,229,489$ & $1,812,854$ \\
\hline 2015 & $5,439,872$ & $1,730,371$ & $3,709,501$ & $(1,519,988)$ \\
\hline 2016 & $7,799,653$ & $2,532,747$ & $5,266,906$ & $1,557,405$ \\
\hline
\end{tabular}

Sumber data diolah

Berdasarkan tabel diatas, diketahui bahwa perkembangan Earning after Tax (EAT) PT. Indofood Sukses Makmur,Tbk dapat dianalisis perkembangan EAT pada tahun 2010 nilai EAT mengalami kenaikan sebesar 1, 078,027 menjadi $3,934,808$, pada tahun 2011 nilai DER mengalami kenaikan kembali

9,568,65menjadi 4,891,673, pada tahun 2012 nilai EAT mengalami Penurunan sebesar112,227menjadi 4,779,446, pada tahun 2013 nilai EAT mengalami penurunan kembali sebesar 1,362,811 menjadi3,416,635,, pada tahun 2014 nilai EAT mengalami peningkatan sebesar1,812,854menjadi $5,229,489$, pada tahun 2015 nilai DER mengalami penurunan sebesar1,519,988 menjadi 1,519,988 dan pada tahun 2016 nilai EAT mengalami kenaikan sebesar 1,557,405menjadi 5,266,906

Dapat dilihat pada tabel diatas Earning After Tax (DER) mengalami penurunan dan peningkatan. Ketidakstabilan ini didisebabkanoleh naik turunnya laba operasional dan non operasional perusahaan.

\section{Hasil Penelian}

Berdasarkan data pada laporan keuangan PT. Indofood Sukses Makmur Tbkyang sudah diolah dan di kemukakan pada pembahasan dan kembali mengacu kepada batasan masalah dan judul skripsi maka penelitian ini hanya mencakup Current ratio, Debt to Equity Ratio dan Earning After Tax.

a. Deskripsi statistik 
Berdasarkan hasil uji analisa deskipsi statistik yang dilakukan oleh peniliti menggunakan program SPSS versi 22, maka peneliti tampilkan karakteristik sampel yang digunakan dalam penelitian ini, meliputi ; jumlah sampel $(\mathrm{N})$, rata rata sampel (Mean), nilai maksimum, nilai minimum, serta standar deviasi, untuk masing - masing variabel CR, DER, dan EAT sebagai berikut :

Current Ratio padaPT Indofood Sukses Makmur Tbk dalam penelitian tersebut mencapai rata-rata (mean) 173,038 \%. Tidak ada standar khusus berapa besarnya Current Ratio ysng paling baik, namun untuk prinsip ke hati - hatian besarnya Current Ratio sekitar $200 \%$ atau 2 : 1 dianggap baik.Semakin tinggi ratio maka semakin terjamin hutang - hutang perusahaan kepada kreditur.

Berdasarkaan tabel di atas nilai rata-rata (mean) Debt to Equty ratio sebesar 100,725\%. Hal ini menunjukkan bahwa secara statistik, selama periode penelitian rasioDebt to Equity Ratio PT. Indofood Sukses Makmur,Tbkmenunjukan kinerja keuangan perusaahaan kurang baik, karena DER yang baik menurut Kamsir 2008 dibawah 100\%. Semakin tinggi DER maka semkain kurang baik kinerja keuangan perusahaan.

Berdasarkan tabel di atas dapat dilihat Earning After Taxmemiliki memiliki nilai rata-rata (mean) sebesar 4,260,654,88. Earning After Tax yang baik bagi kinerja keuangan perusahaan adalah yang terus mengalami peningkatan .

a. Uji t (Uji Parsial)

1) Pengaruh Current Ratio Terhadap Earning After Tax

Berdasarkan tabel diatas menunjukan nilai Thitung sebesar (0.558 ) dengan signifikasi 0.601, dan Ttabel .Karena Thitung -0558< Ttabel 2,57058, dan signifikasi 0,601 > 0,05 Jadi dapat disimpulkan bahwa Current Ratio secara parsial berpengaruh negatif dan tidak signifikan terhadap Earning After Tax

2) Pengaruh Current Ratio Terhadap Earning After Tax

Berdasarkan tabel diatas menunjukan nilai Thitung sebesar (1.822 ) dengan signifikasi 0.128 , dan Ttabel 2,57058 .Karena Thitung $(-1.822)<$ Ttabel 2,57058, dan signifikasi 0,128>0,05. Jadi dapat disimpulkan bahwaDebt to Equity Ratiosecara parsial berpengaruh negatif dan tidak signifikan terhadap Earning After Tax.

\section{E. Kesimpulan dan Saran}

\section{a. Kesimpulan}

Berdasarkan hasil penelitian, serangkaian pengolahan data dan analisis serta pembahasan mengenai pengaruh variabel Current Ratio dan Debt to Equity Ratio terhadap Earning After Tax, maka dapat ditarik kesimpulan yaitu:

1. Variabel Current Ratio (CR)Thitung sebesar (-0.558) dengan signifikasi 0.601 , dan Ttabel .Karena Thitung $-0558<$ Ttabel 2,57058, dan signifikasi 0,601> 0,05 Jadi dapat disimpulkan bahwa Current Ratio secara parsial berpengaruh negatif dan tidak signifikan terhadap Earning After Tax Pada PT. Indofood Sukses Makmur, Tbk Tahun 2009-2016.

2. Variabel Debt to Equity Ratio(DER)menunjukan nilai Thitung sebesar (-1.822) dengan signifikasi 0.128 , dan Ttabel 2,57058 .Karena Thitung $(-1.822)<$ Ttabel 2,57058, dan signifikasi 0,128>0,05 . Jadi dapat disimpulkan bahwaDebt to Equity Ratiosecara parsial berpengaruh negatif dan tidak signifikan terhadap Earning After Tax. pada PT. Indofood Sukses Makmur, Tbk Tahun 2009-2016

3. Variabel Current Ratio (CR)dan Variabel Debt to Equity Ratio(DER) Fhitung = 2,898, signifikasi sebesar 0,146. Nilai Fhitung2,898< Ftabel 5,79, nilai signifikasi $0,146>0,05$. Maka dapat disimpulkan bahwa variable independen (Current Ratio 
dan Debt to Equity Ratio) secara bersama - sama berpengaruh positif dan tidak signifikan terhadap nilai variabel dependen (Earning After Tax). Hasil penelitian ini mendukung penelitian Hariman Naibaho (2014) yang menyatakan bahwa Current Ratio dan Debt to Equity Ratio tidak berpengaruh signifikan terhadap Earning After Tax

\section{b. Saran}

Berdasarkan pembahasan dan kesimpulan penelitian ini serta hasil dari analisis data yang telah diteliti, maka peneliti memberikan saran-saran sebagai berikut:

1. PT. Indofood Sukses Makmur, Tbk kedepannya harus terus menjaga tingkat Current Ratio setiap tahunnya agar mengalami kenaikan yaitu dengan mengimbangi jumlah hutang lancar dengan jumlah aktiva lancar.

2. PT. Indofood Sukses Makmur, Tbk kedepannya harus bias menekan tingkat Debt to Equity Ratio setiap tahunnya agar mengalami penurunan yaitu dengan mengurangi pemijaman dana yang nantinya akan menjadi kewajiban/hutang, karena jika bertambah terus menerus akan memperbanyak ketergantungan jumlah modal sendiri / total ekuitas yang ditanggung oleh hutang.

3. PT. Indofood Sukses Makmur, Tbk harusterus bisa meningkatkan tingkat laba setelah pajaknya / Earning After Tax agar terus mengalami kenaikan yaitu dengan meningkatkan pendapatan non operasional dan operasional.

4. Untuk peneliti yang akan melakukan penelitian selanjutnya dan mengunakan rasio keuangan disarankan untuk lebih jauh menganalisis hubungan dan pengaruh antara rasio dengan menambah variabel bebas yang diteliti dan menambah periode pada tahun laporan keuangan yang akan dilakukan penelitian.

5. Sehubungan dalam penelitian ini, hanya variabel yang berhubungan dengan rasio keuangan, maka dengan penelitian selanjutnya, disarankan untuk memperhatikan faktor-faktor lain yang mungkin dapat berpengaruh diluar dari variabel yang berhubungan dengan rasio keuangan.

\section{F. Daftar Pustaka}

Buku :

AgusHarjito dan Martono, "Manajemen Keuangan, Edisi Kedua, Cetakan Pertama", Penerbit EKONISIA, Yogyakarta, 2011.

Brealey,Myers dan Marcus, "Dasar - Dasar Manajemen Keuangan Perusahaan", Erlangga, Jakarta, 2011.

Charles T.Horngren dan Walter T.Harrison, “Akuntansi jilid Satu. Edisi Tujuh”. Erlangga, Jakarta, 2007.

Darsono, “Manajemen Keuangan”, Diadit Media: Jakarta ,2006.

Fahmi, Irham, “Pengantar Pasar Modal”, Alabeta, Bandung, 2012.

Fathoni, Abdurrahmat ," Metodologi Penelitian dan Teknik Penyusunan Skripsi", PT.Rineka Cipta, Jakarta ,2011.

Hanafi,Mahmud M, "Manajemen keuangan", Cetakan kelima, BPFE :Yogyakarta,2010.

Hani ,Handoko T, “Manajemen edisi ke dua “,BPFE Yogyakarta, 2011. 
Hasibuan, Malayu S.P, “Manajemen Sumber Daya Manusia”, PT Bumi Aksara, Jakarta, 2010.

Husein,Umar, "Riset Akuntansi”, Gramedia Pustaka Utama, Jakarta, 2008.

Ikatan Akuntansi Indonesia, "Standar Akuntansi Keuangan", Salemba Empat, Jakarta, 2012.

Kasmir."Analisis Laporan Keuangan". Jakarta: PT Raja Grafindo Persada, 2010.

Kosasih \& Soewedo, "Manajemen Perusahaan Pelayaran", PT. Rajagrafindo Persada : Jakarta , 2009.

Munawir, S. “Analisa Laporan Keuangan”, Liberty: Yogyakarta, 2010.

Priyatno, Duwi “Mandiri Belajar Analisis Data Dengan SPSS. Mediakom”, 2013

Riyanto,Bambang,"dasar dasar pembelanjaan perusahaanedisi keempat", BPFE Yogyakarta, 2011.

Sarwono, Jonathan, "Analisis Jalur Untuk Riset Bisnis dengan SPSS", Andi , Yogyakarta, 2007.

Sofyan Syafri Harahap, “Analisis Kritis Atas Laporan Keuangan”, Raja grafindo Persada, Jakarta, 2011.

Solihin ,ismail, “Pengantar manajemen”, Erlangga :Jakarta, 2009.

Sugiyono “Metode penelitian Kuantitatif dan Kualitati”, Alfabeta, Bandung , 2010.

Internet :

https://datakata.wordpress.com/2014/11/28/laba-dan-pengaruh-rasio-keuangan-terhadap$\underline{\mathrm{laba}}$

www.indofood.com

www.idx.co.id 